DE

M E D I C I N A

T R O P I C A L

$\mathrm{DE}$

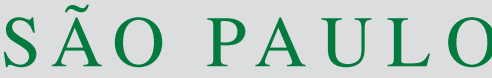

JOURNAL OF THE SÃO PAULO INSTITUTE OF TROPICAL MEDICINE

1 Universidade Federal de Goiás, Laboratório de Parasitologia, Jataí, Goiás, Brazil

${ }^{2}$ Universidade Federal de Goiás, Programa de Pós-Graduação em Ciências Aplicadas à Saúde, Jataí, Goiás, Brazil

Correspondence to: Rosângela Maria Rodrigues

Universidade Federal de Goiás, Laboratório de Parasitologia, Regional Jataí, Câmpus Cidade Universitária, BR 364, Km 195, No 3800, CEP 75801-615, Jataí, GO, Brazil. Tel: +55 64 36068286; Fax: +55 64 36068203

E-mail: rosismaria@yahoo.com.br

Received: 18 September 2017

Accepted: 18 January 2018

\section{Opportunistic and non-opportunistic intestinal parasites in HIV/ AIDS patients in relation to their clinical and epidemiological status in a specialized medical service in Goiás, Brazil}

\author{
Natane Barbosa Barcelos ${ }^{1,2}$, Lorena de Freitas e Silva1, Regyane Ferreira \\ Guimarães Dias², Hélio Ranes de Menezes Filho², Rosângela Maria \\ Rodrigues $^{1,2}$
}

\section{ABSTRACT}

Patients infected with the Human Immunodeficiency Virus (HIV) often have opportunistic infections, among which strongyloidiasis and coccidiosis are the most common parasitic infections that aggravate their health status. This study examined the prevalence of intestinal parasites, particularly of Strongyloides stercoralis and intestinal coccidia in patients with the Human Immunodeficiency Virus (HIV)/ Acquired Immunodeficiency Syndrome (AIDS) who were treated at the Specialized Assistance Service (SAE) of Jataí, State of Goiás, Brazil, and analyzed its correlation with clinical, laboratory, and socio-epidemiological parameters. A total of 270 stool samples were analyzed by the Lutz technique, Rugai's method, Agar Plate Culture, Ritchie's method and specific staining, Ziehl-Neelsen modified technique, Kinyoun's method and the rapid safranin method. The prevalence of intestinal parasites was $28.88 \%$ including $3.8 \%$ of S. stercoralis, Cryptosporidium sp. and Cystoisospora belli. There was a significant positive correlation between intestinal parasites and the clinical status and the use of antiretroviral therapy (ART), smoking, CD4+ lymphocyte counts and sexual orientation. In conclusion, the widespread use of antiretroviral therapy and health assistance contributed to the low prevalence of S. stercoralis and coccidiosis in patients with HIV/ AIDS who were followed up at the SAE.

KEYWORDS: Coccidiosis. Human immunodeficiency virus. Strongyloidiasis. Prevalence

\section{INTRODUCTION}

Intestinal parasitic infections are a serious public health problem in developing countries, where poor nutrition is associated with poor hygiene, poor environmental sanitation, inadequate access to potable water and several coinfections ${ }^{1,2}$. In Brazil, the tropical climate favors the spread of parasites because it provides ideal conditions for them to complete their life cycle and perpetuate new hosts to contaminate the environment ${ }^{3}$.

Parasitic infections are an important cause of morbidity and mortality, especially with the emergence of immunosuppressive diseases ${ }^{4,5}$. After the advent of the human immunodeficiency virus (HIV)/ acquired immunodeficiency syndrome (AIDS) in the world, intestinal parasites that caused only sporadic or zoonotic, benign and asymptomatic infections, have become opportunistic parasites and caused severe episodes of diarrhea in patients with HIV/ $\mathrm{AIDS}^{6,7}$. 
The occurrence of diarrheal stools is considered a marker of poor prognosis, being an evolutionary predictor of $\mathrm{AIDS}^{8}$. The most prominent enteroparasitoses in patients with HIV/ AIDS are caused by Strongyloides stercoralis nematodes and intestinal coccidia that are members of the Apicomplexa phylum, which usually aggravate the clinical condition of immunocompromised patients and cause refractory infections ${ }^{9,10}$. Because of the chronic and recurrent nature of these infections, the intention of this study was to make the diagnosis of Strongyloides stercoralis and Cryptosporidium sp., Cystoisospora belli and Cyclospora cayetanensis through specific techniques in order to determine the prevalence of these intestinal parasites in HIV-positive/ AIDS patients in order to direct strategies for diagnosis and prevention.

\section{MATERIALS AND METHODS}

\section{Characterization of patients and study site}

The study participants were adult patients (aged over 18 years old) of both genders, with HIV/ AIDS, who had not used anthelmintics in the previous six months and were followed up at the Specialized Assistance Service (SAE) of Dr. Serafim Carvalho Municipal Health Center, in the city of Jataí, State of Goiás, Brazil, between June 2015 and March 2016. The Research Ethics Committee of the Universidade Federal de Goiás (Jataí, GO, Brazil) approved the study protocol (process $\mathrm{N}^{\circ} 1079116 / 2015$ ) and all the participants signed an informed consent form.

\section{Study design and delivery of stool samples}

Patients who attended medical consultations were invited to meet the researcher, who clarified all the study objectives and the patients' doubts about them. Individuals who agreed to participate in the study signed the informed consent form and answered a socio-epidemiological questionnaire containing questions related to the variables: gender, age group, type of residence, water treatment, sewerage system, hand washing, number of bowel movements per day, aspects of feces, blood/ mucus in stool, clinical status, CD4+ T-cell count, viral load, taking ART or not and sexual orientation. Patients were instructed on how to collect their stool samples and received vials identified with the initials of their names and the sample number. Fecal samples were stored, further processed and analyzed in the Parasitology Laboratory of the Universidade Federal de Goiás (Jataí, GO, Brazil).
Techniques for parasitological diagnosis of fecal samples

From each participant, three fecal samples were collected on alternate days at the patient's home and delivered to the researcher. Each fresh stool specimen was processed using the following methods: the method described by Lutz ${ }^{11}$, also known as Hoffman, Pons and Janer's method ${ }^{12}$ or yet the spontaneous sedimentation, which allows detection of helminth eggs and larvae, as well as protozoan cysts ${ }^{13}$; the Rugai's method ${ }^{14}$, which is suitable for detection of S. stercoralis and hookworm larvae; the agar plate culture $\operatorname{method}^{15,16}$; and the Ritchie technique ${ }^{17}$ to concentrate samples to prepare fecal smears. The Ziehl-Neelsen method, the Kinyoun's method and the safranin technique ${ }^{18,19}$ were used to identify Cryptosporidium sp, C. belli, and $C$. cayetanensis. Three slides of each sample were prepared and examined by two analysts, i.e., six slides per sample were analyzed. The slides from samples processed through the Lutz, Rugai and agar plate culture techniques were analyzed by light microscopy under 100- and 400-fold magnification. To identify intestinal coccidia, the slides were analyzed under 1,000-fold magnification using immersion oil. When no parasites and/ or commensals were found in the sample, two additional slides were prepared to confirm the result.

\section{Statistical analysis}

Statistical analysis was performed using the GraphPad Prism version 5.0 software (GraphPad Software, Inc., San Diego, USA). Data were analyzed by the t-test (student), chi-square, one-way ANOVA and the Fisher's exact test when appropriate. The magnitude of association between variables was estimated by the odds ratio (OR) with a $95 \%$ confidence interval (95\% CI). The level of significance was set at $\mathrm{p}<0.05$.

\section{RESULTS}

Three fecal samples were collected from each one of the 90 patients with HIV/ AIDS. Forty-nine (54.44\%) participants were female and $41(45.55 \%)$ were male. Their age ranged from 23 to 77 years old, with mean \pm SD of 42 \pm 11.61 , and predominance of women aged 31 to 40 years (16 or $17.7 \%$ ) and men aged 41 to 50 years (15 or 16.6\%). There was no significant difference between the variables gender and age of all the patients analyzed $(\mathrm{p}=0.7132$, $\left.\mathrm{p}=0.7132 ; \chi^{2}=2,914,5\right)$. HIV-infected patients of both genders were positive for intestinal parasites: $13 / 41$ infected men and 13/49 infected women (Table 1). There was no significant difference in positivity regarding the genders. 
Table 1 - Prevalence of intestinal parasites according to age and gender in patients with HIV/ AIDS patients, Jataí, State of Goiás, Brazil $(\mathrm{N}=90)$

\begin{tabular}{lcccc}
\hline \multirow{2}{*}{ Age range (years) } & \multicolumn{2}{c}{ Patients HIV/AIDS } & \multicolumn{2}{c}{ Infected with Protozoans/S. stercoralis } \\
\cline { 2 - 5 } & Male & Female & Male & Female \\
\hline 21 a 40 & $19(46,3 \%)$ & $25(51 \%)$ & $7(53,8 \%)$ & $7(53,8 \%)$ \\
$>41$ & $22(53,6 \%)$ & $24(50 \%)$ & $6(46,1 \%)$ & $6(46,1 \%)$ \\
\hline Total & 41 & 49 & 13 & 13 \\
\hline
\end{tabular}

The risk factors associated with transmission of intestinal parasitic infection in patients with HIV/ AIDS are presented in Table 2. The incidence of parasitic infections was strongly associated with individuals living in recovery houses (OR: 7.588; 95 \% CI: 0.2 to 192.6). Presence of blood in patients' stools increased the probability of intestinal parasitic infection (OR: 2.251; 95\% CI: 0.7 to 6.8); however, there was no statistical significant difference. The univariate analysis evidenced a significant association between the patients' clinical status and the risk of parasitic infection (OR: 11.42; $\mathrm{p}=0.002$ ). The use of ART and the incidence of parasitic infection were also significantly different $(\mathrm{p}=0.041)$ (Table 2).

Analysis of the prevalence of intestinal parasites stratified by HAART (highly active antiretroviral therapy) and non-HAART revealed the strongest correlations with infections caused by the commensal Endolimax nana (OR: 2.33; IC95 0.21 to 24.9) and Entamoeba coli (OR: 2.20; IC95: 0.10 to 46.4 ), with significant differences ( $\mathrm{p}=0.0094)$ (Table 3). Analysis of the clinical and laboratory variables of patients with diarrhea evidenced that $\mathrm{CD}^{+} \mathrm{T}$ counts $(<200$ cells/ $\mathrm{mm}^{3}$ ) and viral load (between 10,001 and 100,000) increased the probability of diarrhea (OR: 1.434; CI 95\%: 0.35 to 5.7; OR: 4.911 ; CI 95\%: 0.8 to 26.9 , respectively), but not in a significant manner ( $\mathrm{p}>0.05$ ) (Table 4).

Table 5 summarizes the significant associations between the incidence of different intestinal parasitic species and CD4+ T-cell counts. Cell counts $>500$ cells/ $\mathrm{mm}^{3}$ were positively associated with monoparasitism $(p=0.0132)$. The type of sexual relationship significantly influenced $(p=0.0001)$ the parasitic associations with monoparasitism.

\section{DISCUSSION}

Opportunistic infections are common in patients with HIV/ AIDS and are related to high morbidity in this population $^{20,21}$. The HIV virus induces an immunodeficient state that favors infection by enteroparasites ${ }^{22}$, which, in turn, contributes to worsen the patients' clinical condition by causing malnutrition, weight loss, and chronic diarrhe $\mathrm{a}^{23-25}$. The Epidemiological Bulletin of the State of Goiás, Brazil, reported 8,785 cases of AIDS in individuals aged over 13 years in the period between 2002 and $2015^{26}$. In this context, the present study examined the occurrence of intestinal parasites in patients with HIV/ AIDS who were treated at the SAE.

The socio-epidemiological profile of the studied patients, whose ages ranged from 23 to 77 years, with predominance of the age groups 31-40 years and 41-50 years old, corroborates the national data reported by Bertoni et al. ${ }^{27}$. As the 31-40 age group corresponds to active individuals with respect to their capacity to work, procreate, and have sexual intercourses, the prevalence of HIV-infected people in this age group can result in significant damage to the population and the economic development of the country $^{28}$.

Detection of S. stercoralis, Cryptosporidium sp. and C. belli in $3.8 \%$ of the fecal samples of patients with HIV/AIDS was lower than the prevalence reported by SoúzaJunior and Garcia-Zapata ${ }^{29,30}$ in a similar study conducted in Goiânia, Goiás. It is important to note that there are few studies on the prevalence of intestinal parasites, including S. stercoralis and intestinal coccidia, in patients with HIV/AIDS in the State of Goiás - this is the first study carried out in the Southwestern region of this State.

The frequency of commensal protozoa is $35,8 \%$ in patients with HIV/ AIDS from Rio de Janeiro ${ }^{24}$. The high positivity rate for commensals observed in the present study may be considered an indicator of poor hygiene and sanitation, as well as of consumption of contaminated water and food by these patients ${ }^{31}$. Good hygiene habits are the best way to avoid contamination and reinfection by intestinal parasites and health security is necessary for the prevention of diseases transmitted by water and food ${ }^{32}$. Food handlers are unaware of the safety procedures for the handling, disposal and storage of food ${ }^{33}$, and patients with HIV/ AIDS do not adopt food safety practices, making them more susceptible to this source of parasitic infection ${ }^{34}$.

The poor management of water and sewage services, associated with the lack of regulation and public policies represent a serious problem in Brazil. Unfortunately, most of these services dump garbage and sewage directly into 
Table 2 - Demographic, clinical and laboratory characteristics of patients with HIV/ AIDS in Jataí, State of Goiás, Brazil (N=90)

\begin{tabular}{|c|c|c|c|c|c|c|}
\hline \multirow{2}{*}{ Features } & \multicolumn{2}{|c|}{ Protozoans and Helminths } & \multirow{2}{*}{ Total(\%) } & \multirow{2}{*}{ OR } & \multirow{2}{*}{ IC-95\% } & \multirow{2}{*}{$p$ value } \\
\hline & Infected & No Infected & & & & \\
\hline \multicolumn{7}{|l|}{ Sex } \\
\hline Male & $13(50)$ & $28(43,75)$ & $41(45,55)$ & 1,286 & $0.5-3.2$ & 0,644 \\
\hline Female & $13(50)$ & $36(56,25)$ & $49(54,44)$ & & & \\
\hline \multicolumn{7}{|l|}{ Age group (years) } \\
\hline 21 a 30 & $6(23,07)$ & $10(15,62)$ & $16(17,77)$ & 1,620 & $0.5-5.0$ & 0,543 \\
\hline 31 a 40 & $7(26,92)$ & $21(31,25)$ & $27(30)$ & 0,810 & $0.2-2.2$ & 0,802 \\
\hline 41 a 50 & $6(23,07)$ & $21(32,81)$ & $27(30)$ & 0,614 & $0.2-1.7$ & 0,451 \\
\hline 51 a 60 & $5(19,23)$ & $9(14,06)$ & $14(15,55)$ & 1,455 & $0.4-4.8$ & 0,535 \\
\hline$>60$ & $2(7,69)$ & $3(4,6)$ & $5(5,55)$ & 1,694 & $0.2-10.7$ & 0,624 \\
\hline \multicolumn{7}{|l|}{ Type of residence } \\
\hline Own home & $11(42,30)$ & $31(48,43)$ & $42(46,66)$ & 0,780 & $0.31-1.9$ & 0,646 \\
\hline Rented house & $8(30,76)$ & $14(21,87)$ & $22(24,44)$ & 1,587 & $0.57-4.4$ & 0,421 \\
\hline Earned home & $3(11,53)$ & $7(10,93)$ & $10(11,11)$ & 1,062 & $0.25-4.4$ & 1,000 \\
\hline Home courtesy & $3(11,53)$ & $11(17,18)$ & $14(15,55)$ & 0,628 & $0.16-2.4$ & 0,749 \\
\hline Recovery House & $1(3,84)$ & - & $1(1,11)$ & 7,588 & $0.29-192$ & 0,288 \\
\hline Did not & - & $1(1,56)$ & $1(1,11)$ & 0,798 & $0.03-20$ & 1,000 \\
\hline \multicolumn{7}{|l|}{ Water treatment } \\
\hline Mineral water & $1(3,84)$ & $1(1,56)$ & $2(1,11)$ & 2,520 & $0.1-41.9$ & 0,496 \\
\hline Filtered water & $11(42,30)$ & $31(48,43)$ & $42(46,66)$ & 0,780 & $0.3-1.9$ & 0,646 \\
\hline No treatment & $14(53,84)$ & $32(50)$ & $46(51,11)$ & 1,167 & $0.4-2.9$ & 0,818 \\
\hline \multicolumn{7}{|l|}{ Sewerage system } \\
\hline Yes & $15(57,69)$ & $34(53,12)$ & $49(54,44)$ & 1,203 & $0.4-3.0$ & 0,816 \\
\hline No/ do not know & $11(42,30)$ & $30(46,87)$ & $41(45,55)$ & & & \\
\hline \multicolumn{7}{|l|}{ Wash hands } \\
\hline Yes & $25(27,77)$ & $58(90,62)$ & $83(92,22)$ & 2,586 & $0.2-22.6$ & 0,668 \\
\hline No & $1(3,84)$ & $6(9,37)$ & $7(7,77)$ & & & \\
\hline \multicolumn{7}{|c|}{ Number of bowel movements per day } \\
\hline 1 a 2 & $21(80,76)$ & $47(73,43)$ & $68(75,55)$ & 1,519 & $0.4-4.6$ & 0,592 \\
\hline 3 a 4 & - & $8(12,5)$ & $8(8,88)$ & 0,125 & $0.06-2.2$ & 0,099 \\
\hline 5 a 6 & - & $1(1,56)$ & $1(1,11)$ & 0,798 & $0.03-20$ & 1,000 \\
\hline Do not know & $5(19,23)$ & $8(12,5)$ & $13(14,44)$ & 1,667 & $0.4-5.6$ & 0,509 \\
\hline \multicolumn{7}{|l|}{ Aspects of faeces } \\
\hline Diarrheal & $10(38,46)$ & $23(35,93)$ & $33(36,66)$ & 1,114 & $0.4-2.85$ & 0.814 \\
\hline No diarrheal & $16(61,53)$ & $41(64,06)$ & $57(63,33)$ & & & \\
\hline \multicolumn{7}{|l|}{ Blood/mucus in stool } \\
\hline Yes & $4(15.4)$ & $3(4.6)$ & $7(7.80)$ & 3.697 & $0.7-17.8$ & 0.186 \\
\hline No & $22(84.6)$ & $61(95.4)$ & $83(92.2)$ & & & \\
\hline Clinical status & & & & & & \\
\hline AIDS & $7(26,92)$ & $2(3,12)$ & $9(10)$ & 11,42 & $2.1-59.6$ & 0,002 \\
\hline HIV & $19(73,07)$ & $62(96,87)$ & $81(90)$ & & & \\
\hline CD4+T (cels/mm³) & & & & & & \\
\hline$<200$ & $3(11,53)$ & $6(9,37)$ & $9(10)$ & 1,261 & $0.29-5.4$ & 0,714 \\
\hline 200 a 500 & $5(19,23)$ & $7(10,93)$ & $12(13,33)$ & 1,939 & $0.5-6.7$ & 0,317 \\
\hline$>500$ & $18(69,23)$ & $51(79,68)$ & $69(76,66)$ & 0,573 & $0.20-1.6$ & 0,288 \\
\hline Viral charge (copies/ & & & & & & \\
\hline$<$ minimun limit & $14(15,55)$ & $39(60,93)$ & $53(58,88)$ & 0,747 & $0.29-1.8$ & 0,637 \\
\hline$<1.000$ & $4(15,38)$ & $13(20,31)$ & $17(18,88)$ & 0,713 & $0.20-2.4$ & 0,768 \\
\hline $1.001-10.000$ & $4(15,38)$ & $5(7,81)$ & $9(10)$ & 2,145 & $0.5-8.7$ & 0,275 \\
\hline $10.001-100.000$ & $3(11,53)$ & $4(6,25)$ & $7(7,77)$ & 1,957 & $0.40-9.4$ & 0,407 \\
\hline$>100.000$ & $2(7,69)$ & $2(3,12)$ & $4(4,44)$ & 1,240 & $0.1-14.3$ & 1,000 \\
\hline Did not & - & $1(1,56)$ & $1(1,11)$ & 0,798 & $0.03-20$ & 1,000 \\
\hline TARV & & & & & & \\
\hline Yes & $21(80,76)$ & $61(95,31)$ & $82(91,11)$ & 0,206 & $0.04-0.9$ & 0,041 \\
\hline No & $5(19,23)$ & $3(4,68)$ & $8(8,88)$ & & & \\
\hline Sexual orientation & & & & & & \\
\hline Heterossex & $20(76,92)$ & $54(84,37)$ & $74(82,22)$ & 0,617 & $0.19-1.9$ & 0,543 \\
\hline Homossex & $1(3,84)$ & $5(7,81)$ & $6(6,66)$ & 0,472 & $0.05-4.2$ & 0,668 \\
\hline Bisex & $4(15,38)$ & $2(3,12)$ & $6(6,66)$ & 5,636 & $0.9-32.9$ & 0,055 \\
\hline Unknown & $1(3,84)$ & $3(4,68)$ & $4(4,44)$ & 0,813 & $0.08-8.2$ & 1,000 \\
\hline Total & $26(28,88)$ & $64(71,11)$ & $90(100)$ & & & \\
\hline
\end{tabular}

No - number, OR - Odd ratio, IC 95\% - Confidence interval, $p$ value - significant when $p<0.05$. 
Table 3 - Relationship between HAART and Non-HAART and infection with intestinal parasites in patients HIV/ AIDS in Jataí, State of Goiás, Brazil $(\mathrm{N}=90)$

\begin{tabular}{|c|c|c|c|c|c|}
\hline $\begin{array}{l}\text { Prevalence of intes- } \\
\text { tinal parasites }\end{array}$ & $\begin{array}{l}\text { HAART } \\
(\mathrm{N}=81)\end{array}$ & $\begin{array}{l}\text { NON-HAART } \\
\quad(\mathrm{N}=9)\end{array}$ & OR & Cl $95 \%$ & $p$ value \\
\hline E. nana & 14 & 1 & 2.33 & $0.21-24.9$ & 0.6257 \\
\hline E. hartmanni & 5 & 2 & 0.18 & $0.02-1.63$ & 0.1626 \\
\hline E. coli & 6 & 0 & 2.20 & $0.10-46.4$ & 1.0000 \\
\hline B. hominis & 2 & 0 & 0.73 & $0.03-18.0$ & 1.0000 \\
\hline G. lamblia & 1 & 0 & 0.42 & $0.01-12.2$ & 1.0000 \\
\hline I. butschlii & 1 & 0 & 0.42 & $0.01-12.2$ & 1.0000 \\
\hline E. histolytica/dispar & 1 & 0 & 0.42 & $0.01-12.2$ & 1.0000 \\
\hline C. belli & 0 & 1 & 0.035 & $0.001-1.0$ & 0.1111 \\
\hline Cryptosporidium sp. & 1 & 0 & 0.42 & $0.01-12.2$ & 1.0000 \\
\hline S. stercoralis & 1 & 0 & 0.42 & $0.01-12.2$ & 1,0000 \\
\hline Total & 32 & 4 & & & \\
\hline
\end{tabular}

OR - odds ratio, $\mathrm{Cl} 95 \%$ - confidence interval, $p$ value of Mann-Whitney $=0,0094 ;\left(p<0.05^{\star *}\right)$.

Table 4 - Analysis of clinical and laboratory parameters of the 90 patients with HIV/ AIDS stratified by the presence of diarrhea in Jataí, State of Goiás, Brazil

\begin{tabular}{|c|c|c|c|c|c|c|}
\hline \multirow{2}{*}{ Variables } & & \multicolumn{2}{|c|}{ Diarrhea } & \multirow[t]{2}{*}{ OR } & \multirow[t]{2}{*}{ IC 95\% } & \multirow[t]{2}{*}{$p$ value } \\
\hline & & YES (\%) & NO (\%) & & & \\
\hline \multirow{3}{*}{$\begin{array}{l}\text { CD4+T } \\
\left(\text { cells/mm }{ }^{3}\right)\end{array}$} & $<200$ & $4(12,12)$ & $5(8,77)$ & 1,434 & $0.3568-5.767$ & 0,7197 \\
\hline & $200-500$ & $4(12,12)$ & $8(14,03)$ & 0,8448 & $0.2336-3.055$ & 1,0000 \\
\hline & $>500$ & $25(75,75)$ & $44(77,19)$ & 0,9233 & $0.3368-2.531$ & 1,0000 \\
\hline \multirow{6}{*}{$\begin{array}{l}\text { Viral charge } \\
\text { (copies/mL) }\end{array}$} & $<$ minimum & $20(60,60)$ & $33(57,89)$ & 1,119 & $0.4667-2.682$ & 0,8278 \\
\hline & $<1000$ & $6(18,18)$ & $11(19,29)$ & 0,9293 & $0.3085-2.799$ & 1,0000 \\
\hline & $1.001-10.000$ & $1(3,03)$ & $8(14,03)$ & 0,1914 & $0.02282-1.605$ & 0,1467 \\
\hline & $10.001-100.000$ & $5(15,15)$ & $2(3,50)$ & 4,911 & $0.8951-26.94$ & 0,0951 \\
\hline & $>100.000$ & $1(3,03)$ & $2(3,50)$ & 0,8594 & $0.07488-9.863$ & 1,0000 \\
\hline & Did not & - & $1(1,75)$ & 0,5622 & $0.02224-14.21$ & 1,0000 \\
\hline \multirow{2}{*}{ TARV } & Yes & $31(93,93)$ & $51(89,47)$ & 1,824 & $0.3461-9.608$ & 0,7053 \\
\hline & No & $2(6,06)$ & $6(10,52)$ & & & \\
\hline Total & & $33(36,66)$ & $57(63,33)$ & & & \\
\hline
\end{tabular}

HAART -highly active antiretroviral therapy, OR - Odd ratio, IC 95\% - Confidence interval, $p$ value (significant when $p<0.05$ ).

the soil, rivers and river springs, causing environmental degradation and proliferation of diseases ${ }^{35,36}$. The waterborne diseases, especially those caused by intestinal protozoa, are among the most relevant pathogens of drinking water-associated disease outbreaks ${ }^{37,38}$.

The Coccidia life cycles are suited to waterborne and foodborne transmission and their oocysts are resistant to conventional water treatment protocols ${ }^{39}$. Intestinal parasites are highly prevalent in sludge and sewage, thereby representing potential risks to public health ${ }^{40}$. All the raw water samples from the Atibaia River (Campinas, SP,
Brazil) collected in 2001 were positive for Cryptosporidium spp. and Giardia $\mathrm{spp}^{41}$. Giardia spp. cysts were found in $90.5 \%$ of the raw sewage samples; $96.2 \%$ of treated sewage samples not disinfected by UV lightand $94.7 \%$ of treated wastewater disinfected by UV lights - in other words, the cysts resist to the wastewater treatment process ${ }^{42}$. These reports stress the importance of the parasitological control of water and sludge from municipal power stations and the urgent need to expand sanitation coverage to improve wastewater treatment in Brazil.

Monoparasitism predominated among the study 
Table 5 - Parasitic association stratified by CD4+ T-cell count and sexuality of the 26 patients with HIV/ AIDS who were positive for intestinal parasites in Jataí, State of Goiás, Brazil

\begin{tabular}{|c|c|c|c|c|c|c|c|c|c|c|}
\hline \multirow{2}{*}{ Parasitism } & \multirow{2}{*}{$\mathrm{N}$} & \multirow{2}{*}{$\%$} & \multicolumn{3}{|c|}{ CD4+T (cells $\left./ \mathrm{mm}^{3}\right)$} & \multirow{2}{*}{$p$} & \multicolumn{3}{|c|}{ Sexual Orientation (\%) } & \multirow{2}{*}{$p$} \\
\hline & & & $<200$ & $200-500$ & $>500$ & & Homo & Hetero & $\mathrm{Bi}$ & \\
\hline Monoparasitism & 20 & 22,22 & & & & & & & & \\
\hline E. nana & 10 & 11,11 & $1(1,11)$ & $3(3,33)$ & $6(6,66)$ & 0,0132 & - & $8(8,88)$ & $2(2,22)$ & 0,0001 \\
\hline E. hartmanni & 4 & 4,44 & - & - & $4(4,44)$ & & - & $2(2,22)$ & $2(2,22)$ & \\
\hline E. coli & 3 & 3,33 & - & $1(1,11)$ & $2(2,22)$ & & - & $3(3,33)$ & - & \\
\hline B. hominis & 1 & 1,11 & - & - & $1(1,11)$ & & - & $1(1,11)$ & - & \\
\hline S. stercoralis & 1 & 1,11 & - & - & $1(1,11)$ & & - & $1(1,11)$ & - & \\
\hline C. belli & 1 & 1,11 & $1(1,11)$ & & & & - & $1(1,11)$ & - & \\
\hline Biparasitism & 3 & 3,33 & & & & & & & & \\
\hline E. coli + E. nana & 1 & 1,11 & - & - & $1(1,11)$ & & - & $1(1,11)$ & - & \\
\hline E. coli + hartmanni & 1 & 1,11 & - & - & $1(1,11)$ & & $1(1,11)$ & - & - & \\
\hline E. nana $+B$. hominis & 1 & 1,11 & $1(1,11)$ & - & - & & - & $1(1,11)$ & - & \\
\hline Polyparasitism & 3 & 3,33 & & & & & & & & \\
\hline $\begin{array}{l}\text { E. nana + E. coli + } \\
\text { I. butschlii }\end{array}$ & 1 & 1,11 & - & - & $1(1,11)$ & & - & $1(1,11)$ & - & \\
\hline $\begin{array}{l}\text { G. lamblia + E. nana + } \\
\text { E. hartmanni }\end{array}$ & 1 & 1,11 & - & - & $1(1,11)$ & & - & $1(1,11)$ & - & \\
\hline $\begin{array}{l}\text { Cryptosporidium sp. + } \\
\text { E. nana + E. histolytica/dis- } \\
\text { par + E. hartmanni }\end{array}$ & 1 & 1,11 & - & $1(1,11)$ & - & & & $1(1,11)$ & & \\
\hline Total & 26 & 28,88 & 3 & 5 & 18 & & 1 & 21 & 4 & \\
\hline
\end{tabular}

participants $(22.22 \%)$, corroborating the findings of Brito et al. ${ }^{43}$ and Marchi Blatt and $\mathrm{Cantos}^{44}$. Parasitic associations were prevalent in patients with CD4+ cell counts greater than 500 cells $/ \mathrm{mm}^{3}$, probably because the majority of study participants were of this group (76.66\%). Analysis of the correlation between parasitic association and the type of sexual intercourse resulted in significant differences $(\mathrm{p}=0.0001)$. The sexual behavior of men having homosexual intercourses is considered a risk factor for infections by Cryptosporidium $\mathrm{sp}^{45}$ and Entamoeba histolytica ${ }^{46}$.

Coinfection of different parasitic species depends on the environmental contamination and increases the probability of polyparasitic contamination ${ }^{47}$. In addition, nutritional and immunological factors of the host are crucial in determining the establishment and the course of parasitic infections ${ }^{48}$. As AIDS causes a progressive immunodeficiency characterized by depletion of CD4+ T-cells, patients with HIV/ AIDS are 11.42 times more likely to develop parasitic infection than healthy individuals (OR: $11.42 ; 95 \%$ CI: 2.18 to 59.6; $\mathrm{p}=0.0020)^{49}$.

The use of antiretroviral therapy provided protection against parasites ( $O R<1, p=0.0419$ ). Patients' high adherence to antiretroviral therapy markedly improves the immune response, slows down the progression of diseaseand reduces the susceptibility to opportunistic infections ${ }^{43,50}$. HIV-infected children who were virgin to antiretroviral therapy had a higher prevalence of intestinal parasites than those undergoing treatment with HAART ${ }^{51}$.

Analysis of medical records showed that most patients who were positive for intestinal parasites showed CD4+ T lymphocyte counts above 500 cells/ $\mathrm{mm}^{3}$ (69.23\%), but there was no significant association ( $p>0.05$ ). The literature reports that the prevalence of intestinal parasites was significantly higher in subjects with CD4+ cell counts below 200 cells $/ \mathrm{mm}^{3}$, proving that CD4+ T lymphocytes are essential to fight against HIV and slow down the progression of AIDS ${ }^{52-54}$. In the present study, patients who were positive for Cryptosporidium sp. and C. belli had CD4+ cell counts of 173 and 282 cells/ $\mathrm{mm}^{3}$, respectively. This finding is in line with the frequent infection by intestinal Coccidia found in patients with low CD4+ cell counts ${ }^{55-57}$.

The presence of diarrhea did not significantly correlate with infection by intestinal parasites, corroborating the findings of Bachur et al. ${ }^{58}$ and Wanyiri et al. ${ }^{59}$. In contrast, Pavie et $a l .{ }^{60}$ have reported a positive relationship between diarrhea and intestinal parasites positive samples, while Attili et al..$^{61}$ reported that protozoa infections are associated 
with a higher incidence of diarrhea in HIV-infected individuals than in the general population. Other causes of diarrhea in patients with HIV/ AIDS are infection by other pathogens, such as bacteria, fungi and viruses; entheropathy caused by HIV and side effects of HAART ${ }^{62}$.

Antiretroviral therapy has gradually reduced the incidence of opportunistic infections in patients with HIV/ AIDS. However, poor adherence to treatment negatively affects the effectiveness of antiretroviral therapy and the prognosis of patients. The time between the diagnosis of infection and the onset of AIDS, adverse drug reactions, the patient's age and education level, and the use of illicit drugs are the main reasons reported for non-compliance to treatment ${ }^{63}$. A recent study revealed that most patients (98.3\%) stop taking the medication due to psychological reasons, which can reduce the effectiveness of antiretroviral therapy and increase the susceptibility to opportunistic infections ${ }^{64}$.

In conclusion, the prevalence of intestinal parasites found in this study has attracted the attention of health professionals to the need for parasitological examinations in the routine treatment of patients with HIV/ AIDS, including specific tests, given the clinical importance of these diseases in the evolution to AIDS. In addition, this study demonstrates the risk behaviors for the infection by enteroparasites according to the epidemiological scenario in Jataí, and evidences the need to implement preventive measures to reduce infection rates and prevent the worsening of the patients' clinical conditions.

\section{ACKNOWLEDGMENTS}

We are grateful to Prof. Marta Benedita, $\mathrm{PhD}$, from the Coccidia Laboratory of the Universidade Federal do Triângulo Mineiro, for her assistance during technical standardization. Financial Support: Natane Barbosa Barcelos was the recipient of a fellowship from the Fundação de Amparo à Pesquisa do Estado de Goiás (FAPEG) for conducting the present study (grant $\mathrm{N}^{\circ}$ 2014/10267600428).

\section{CONFLICT OF INTERESTS}

The authors declare that they have no conflict of interest.

\section{REFERENCES}

1. Wegayehu t, Tsalla T, Seifu B, Teklu T. Prevalence of intestinal parasitic infections among highland and lowland dwellers in Gamo area, South Ethiopia. BMC Public Health. 2013;13:151.

2. World Health Organization. Control of tropical diseases. Geneva: WHO; 1998.
3. Andrade EC, Leite IC, Rodrigues VO, Cesca MG. Parasitoses intestinais: uma revisão sobre seus aspectos sociais, epidemiológicos, clínicos e terapêuticos. Rev APS. 2010;13:231-40.

4. Chan MS. The global burden of intestinal nematode infections: fifty years on. Parasitol Today. 1997;13:438-43.

5. Santos RB, Fonseca Jr LE, Santana AT, Silva CA, Guedes JC. Clinical, endoscopic and histopathological profiles of parasitic duodenitis cases diagnosed by upper digestive endoscopy. Arq Gastroenterol. 2011;48:225-30.

6. Kelly P. Intestinal protozoa. In: Farrar J, Hotez PJ, Junghanss T, Kang G, Lalloo D, White NJ, editors. Manson's Tropical diseases. 23rd ed. Philadelphia: Elsevier; 2014. p.664-82.

7. Lockwood DN, Weber JN. Parasite infections in AIDS. Parasitol Today. 1989;5310-6.

8. Slifko TR, Smith HV, Rose JB. Emerging parasite zoonoses associated with water and food. Int J Parasitol. 2000;30:137993.

9. Paboriboune P, Phoumindr N, Borel E, Sourinphoumys K, Phaxayaseng S, Luangkhot E, et al. Intestinal parasitic infections in HIV-infected patients, Lao People's Democratic Republic. Plos One. 2014;9:e91452.

10. Requena I, Añez H, Lacourt E, Blanco E, Castillo H, Rivera M, et al. Elevada prevalencia de coccidios intestinales en pacientes infectados con el Virus de La Inmunodeficiencia Humana em Ciudad Bolívar, Venezuela. Rev Biomed. 2007;18:73-5.

11. Lutz A. O Schistosomum mansoni e a Schistosomatose segundo observações, feitas no Brazil. Mem Inst Oswaldo Cruz. 1919;11:121-55.

12. Hoffmann WA, Pons JA, Janer JL. The sedimentationconcentration method in Schistosomiasis mansoni, Puerto Rico J Public Health Trop Med. 1934;9:283-91.

13. Rocha MO, Mello RM. Exame parasitológico de fezes. In: Neves DP, Melo AL, Linardi PM, Vitor RW, editores. Parasitologia humana. 12a ed. São Paulo: Atheneu; 2011. p.509-22.

14. Rugai E, Mattos T, Brisola AP. Nova técnica para isolar larvas de nematóides das fezes: modificação do método de Baermann. Rev Inst Adolfo Lutz. 1954;14:5-8.

15. Arakaki T, Hasegawa H, Asato R, Ikeshiro T, Kinjo F, Saito A, et al. A new method to detect Strongyloides stercoralis from human stool. Jpn J Trop Med Hyg. 1988;16:11-7.

16. Mühlhauser M, Rivas LM. Strongyloides stercoralis. Rev Chilena Infectol. 2013;30:513-4.

17. Ritchie LS. An ether sedimentation technique for routine stool examination. Bull U S Army Med Dep. 1948;8:326.

18. Oliveira-Silva MB, Oliveira LR, Resende JC, Peghini, BC, Ramirez LE, Lages-Silva E, et al. Seasonal profile and level of CD4+ lymphocytes in the occurrence of cryptosporidiosis and cystoisosporidiosis in HIV/AIDS patients in the Triângulo Mineiro region, Brazil. Rev Soc Bras Med Trop. 2007;40:5125. 
19. Choudhary A, Gupta N, Ahmad H, Mirdha BR. Morphological variations on microscopy in oocysts of coccidian parasites: a prospective study from a tertiary care hospital in north India. Microsc Res Tech. 2017;80:969-72.

20. Scott L, Silva P, Boehme CC, Stevens W, Gilpin CM. Diagnosis of opportunistic infections: HIV co-infections - tuberculosis. Curr Opin HIV AIDS. 2017;12:129-38.

21. Ramesh K, Gandhi S, Rao V. Clinical profile of human immunodeficiency virus patients with opportunistic infections: a descriptive case series study. Int J Appl Basic Med Res. 2015;5:119-23.

22. Dash M, Padhi S, Panda P, Parida B. Intestinal protozoans in adults with diarrhea. N Am J Med Sci. 2013;5:707-12.

23. Portegies P, Berger JR. Introduction to HIV infection and neuroAIDS. In: Portegies P, Berger JR, editors. HIV/AIDS and the nervous system. Edinburgh: Elsevier; 2017. p.1-2. (Handbook of clinical neurology; v.85, 3rd series)

24. Leite MH, Waissmann W. Enteroparasitoses em pacientes ambulatoriais portadores de HIV/AIDS e abastecimento domiciliar de água. Rev Cien Med. 2004;13:363-9.

25. Siddiqi Z, Karoli R, Fatima J, Dey R, Kazmi K. A case of cerebellar dysarthria as the presenting symptom of HIV infection. J Assoc Physicians India. 2014;62:731-3.

26. Goiás. Secretaria de Estado da Saúde. Superintendência de Políticas de Atenção Integral à Saúde. Gerência de Programas Especiais. Coordenação Estadual de DST/Aids. Boletim epidemiológico HIV/Aids Estado de Goiás. Goiânia: Secretaria de Estado da Saúde; 2015.

27. Bertoni RF, Bunn K, Silva J, Traebert J. Perfil demográfico e socioeconômico dos portadores de HIV/AIDS do Ambulatório de Controle de DST/AIDS de São José, SC. Arq Cat Med. 2010;39:75-9.

28. Almeida EL, Araujo GB, Santos VA, Bustorff LA, Pereira AV, Dias MD. Adesão dos portadores do HIV/AIDS ao tratamento: fatores intervenientes. REME Rev Min Enferm. 2011;15:208-16.

29. Souza Jr ES, Garcia-Zapata MT. Diagnóstico laboratorial de enteroparasitoses oportunistas, com ênfase nas microsporidioses humanas, em Goiânia-GO. Rev Soc Bras Med Trop. 2006;39:560-4.

30. Garcia-Zapata MT, Manzi RS, Souza Jr ES, Fagundes GM, Macedo DF, Barros DA, et al. Diagnóstico laboratorial dos enteroparasitos oportunistas em pacientes $\mathrm{HIV}^{+}$no hospital de doenças tropicais, Goiânia-GO, Brasil: estudo retrospectivo (1996-1999). Rev Patol Trop. 2004;33:81-90.

31. Saturnino AC, Nunes JF, Silva EM. Relação entre ocorrência de parasitas intestinais e sintomatologia observada em crianças de uma comunidade carente de Cidade Nova, em Natal - Rio Grande do Norte, Brasil. Rev Bras Anal Clin. 2003;35:85-7.

32. Medeiros LC, Hillers VN, Kendall PA, Mason A. Food safety education: what should we be teaching to consumers? J Nutr Educ. 2001;33:108-13.
33. Melo AC, Furtado LF, Ferro TC, Bezerra KC, Costa DC, Costa LA, et al. Contaminação parasitária de alfaces e sua relação com enteroparasitoses em manipuladores de alimentos. Rev Trop Cienc Agr Biol. 2011;5:47-52.

34. Leite CA, Succi RC, Patrício FR, Fagundes-Neto U. Aspectos funcionais, microbiológicos e morfológicos intestinais em crianças infectadas pelo vírus da imunodeficiência humana. Arq Gastroenterol. 2006;43:310-5.

35. Libânio PA, Chernicharo CA, Nascimento NO. A dimensão da qualidade de água: avaliação da relação entre indicadores sociais, de disponibilidade hídrica, de saneamento e de saúde pública. Eng Sanit Ambient. 2005;10:219-28.

36. Galvão Jr AC. Desafios para a universalização dos serviços de água e esgoto no Brasil. Rev Panam Salud Publica. 2009;25:548-56.

37. Exner M, Gornik V. Durch Trinkwasser übertragene parasitäre Zoonosen: Giardiasis und Cryptosporidiosis. Bundesgesundheitsblatt Gesundheitsforschung Gesundheitsschutz. 2004;47:698-704.

38. Smith HV, Cacciò SM, Cook N, Nichols RA, Tait A. Cryptosporidium and Giardia as foodborne zoonoses. Vet Parasitol. 2007;149:29-40.

39. Lee SH, Joung M, Yoon S, Choi K, Park WY, Yu JR. Multiplex PCR detection of waterborne intestinal protozoa: microsporidia, Cyclospora, and Cryptosporidium. Korean J Parasitol. 2010;48:297-301.

40. Santos PR, Daniel LA. Occurrence and removal of Giardia spp. cysts and Cryptosporidium spp. oocysts from a municipal wastewater treatment plant in Brazil. Environ Technol. 2017;38:1245-54.

41. Franco RM, Rocha-Eberhardt R, Cantusio Neto R. Occurrence of Cryptosporidium oocysts and Giardia cysts in raw water from the Atibaia River, Campinas, Brazil. Rev Inst Med Trop Sao Paulo. 2001;43:109-11.

42. Santos LU, Cantusio Neto R, Franco RM, Guimarães JR. Detecção de oocistos de Cryptosporidium spp. e cistos de Giardia spp. em amostras de esgoto bruto ou tratado: avaliação crítica dos métodos. Eng Sanit Ambient. 2011;16:115-20.

43. Brito FG, Rezende MI, Madi RR, Melo CM. Perfil epidemiológico de portadores do vírus da imunodeficiência humana e síndrome da imunodeficiência adquirida no estado de Sergipe, 20072012. Interfaces Cien Saude Ambient. 2014;2:59-71.

44. Marchi Blatt J, Cantos GA. Evaluation of techniques for the diagnosis of Strongyloides stercoralis in human immunodeficiency virus (HIV) positive and HIV negative individuals in the city of Itajaí, Brazil. Braz J Infect Dis. 2003;7:402-8

45. Hellard M, Hocking J, Wilis J, Dore G, Fairley C. Risk factors leading to Cryptosporidium infection in men who have sex with men. Sex Transm Infec. 2003;79:412-4.

46. Hung CC, Ji DD, Sun HY, Lee YT, Hsu SY, Chang SY, et al. Increased risk for Entamoeba histolytica infection and invasive 
amebiasis in HIV seropositive men who have sex with men in Taiwan. PLoS Negl Trop Dis. 2008;2:e175.

47. Santos SA, Merlini LS. Prevalência de enteroparasitoses na população do município de Maria Helena, Paraná. Cienc Saude Colet. 2010;15:899-905.

48. Motta ME, Silva GA. Diarréia por parasitas. Rev Bras Saude Matern Infant. 2002;2:117-27.

49. Paranjape RS. Immunopathogenesis of HIV infection. Indian J Med Res. 2005;121:240-55.

50. Rossi SM, Maluf EC, Carvalho DS, Ribeiro CE, Battaglin CR. Impacto da terapia antirretroviral conforme diferentes consensos de tratamento da AIDS no Brasil. Rev Panam Salud Publica. 2012;32:117-23.

51. Mengist HM, Taye B, Tsegaye A. Intestinal parasitosis in relation to CD4+T cells levels and anemia among HAART initiated and HAART naive pediatric HIV patients in a Model ART center in Addis Ababa, Ethiopia. PloS One. 2015;10:e0117715.

52. Assefa S, Erko B, Medhin G, Assefa Z, Shimelis T. Intestinal parasitic infections in relation to HIV/AIDS status, diarrhea and CD4 T-cell count. BMC Infect Dis. 2009;9:155.

53. Vyas N, Sood S, Sharma B, Kumar M. The prevalence of intestinal parasitic infestation and the related profile of the CD4+ counts in HIV/AIDS people with diarrhoea in Jaipur city. J Clin Diag Research. 2013;7:454-6.

54. Nsagha DS, Njunda AL, Assob NJ, Ayima CW, Tanue EA, Kibu $\mathrm{OD}$, et al. Intestinal parasitic infections in relation to $\mathrm{CD} 4+$ $\mathrm{T}$ cell counts and diarrhea in HIV/AIDS patients with or without antirretroviral therapy in Cameroon. BMC Infect Dis. 2016;16:9.

55. Akinbo FO, Okaka CE, Omoregie R. Prevalence of intestinal parasitic infections among HIV patients in Benin City, Nigeria. Libyan J Med. 2010;5:5506.

56. Mohanty I, Panda P, Sahu S, Dash M, Narasimham MV, Padhi S, et al. Prevalence of isosporiasis in relation to CD4 cell counts among HIV-infected patients with diarrhea in Odisha, India. Adv Biomed Res. 2013;2:61.

57. Assis DC, Resende DV, Cabrine-Santos M, Correia D, OliveiraSilva MB. Prevalence and genetic characterization of Cryptosporidium spp. and Cystoisospora belli in HIV-infected patients. Rev Inst Med Trop Sao Paulo. 2013;55:149-54.

58. Bachur TP, Vale JM, Coêlho IC, Queiroz TR, Chaves CS. Enteric parasitic infections in HIV/AIDS patients before and after the highly active antiretroviral therapy. Braz J Infect Dis. 2008;12:115-22.

59. Wanyiri JW, Kanyi H, Maina S, Wang DE, Steen A, Ngugi P, et al. Cryptosporidiosis in HIV/AIDS patients in Kenya: clinical features, epidemiology, molecular characterization and antibody responses. Am J Trop Med Hyg. 2014;91:319-28.

60. Pavie J, Menotti J, Porcher R, Donay JL, Gallien S, Sarfati C, et al. Prevalence of opportunistic intestinal parasitic infections among HIV-infected patients with low CD4 cells counts in France in the combination antiretroviral therapy era. Int J Infec Dis. 2012;16:e677-9.

61. Attili SV, Gulati AK, Singh VP, Varma DV, Rai M, Sundar S. Diarrhea, CD4 counts and enteric infections in a hospital based cohort of HIV-infected patients around Varanasi, India. BMC Infect Dis. 2006;6:39.

62. Blanshard C, Gazzard BG. Natural history and prognosis of diarrhea of unknown cause in patients with acquired immunodeficiency syndrome (AIDS). Gut. 1995;36:283-6.

63. Silva JA, Dourado I, Brito AM, Silva CA. Fatores associados à não adesão aos antirretrovirais em adultos com AIDS nos seis primeiros meses da terapia em Salvador, Bahia, Brasil. Cad Saude Publica. 2015;31:1188-98.

64. Romeu GA, Tavares MM, Carmo CP, Magalhães KN, Nobre AC, Matos VC. Avaliação da adesão a terapia antirretroviral de pacientes portadores de HIV. Rev Bras Farm Hosp Serv Saúde. 2012;3:37-41. 